\title{
Early Wedding Polemik and The Impact Of The Domestic Violence
}

\section{Edy Supriyanto}

Faculty of Law, MPU Tantular University

edyanto2003@yahoo.com

\section{Fransiska Novita Eleanora}

Faculty of Law, University of Bhayangkara, Greater Jakarta

siska_ita@yahoo.com

DOI: 10.23917/laj.v5i1.9722

\section{Submission \\ Track:}

Received:

31 December 2019

Final Revision:

5 Maret 2020

Available online:

28 April 2020

Corresponding

Author:

Fransiska Novita

Eleanora

siska_ita@yahoo.com

\begin{abstract}
The purpose of this study is to find the polemic of early marriage in domestic violence based on impact and consequences. The research method used is normative jurisdiction in which this method refers to the concept, and the principles and literature, and also legislation that is related to the problem under study. The results of this study indicate that early marriage can cause domestic violence because it is triggered and unprepared for high emotional, mental, psychological impact, which causes violence in the household environment, not only for women but also children who must receive protection and love unfortunately from parents but become victims. The other impact is the child is traumatized and difficult to forget the dark events of his life because the child feels himself a victim of his family. The Conclusion of this study is the renewal of violence in the sphere of households as a result of early marriage can be avoided if each partner is aware of their respective duties and responsibilities and treats his partner fairly, with equality between the parties. This study can be used for studying the role of family, and the relation of early wedding and domestic violence
\end{abstract}

Keywords: early marriage, violence, domestic, Family

\section{INTRODUCTION}

Protection of the existence of the rights of every person to the creation of God Almighty has become the obligation of the Government, the State, and the Law to protect it. Everyone 
respects and respects the protection and existence of these rights. The intended protection is not only a mere figment or just verbally but to provide a strong basis by issuing various regulations governing the protection of women and children. The protection provided includes protection in the smallest sphere, namely the family, meaning that the family as a base of love, the outpouring of feelings should not take actions that are considered to have an adverse effect and effect on those within the scope of a family or household. Data from the National Commission on Violence Against Women, the number of violence against women, continued to increase by $14 \%$ from 2018 to 2019, which amounted to 406,178 cases. And from these data, many rapes against marriage, violence in courtship, cybercrime, and rape of women with disabilities or disabilities. (Runi, 2019).

Abuse in marriage ranks first, where it can be interpreted in the scope of the household. It has an effect on children. Domestic violence due to marriage at a young age is very improper to apply or occur to children who should be educated and play. Still, care must be taken and supervision of their children, so that early marriage does not happen at a young age (Hartono, 2014).

The cause of marriage at a very young age is due to the occurrence of pregnancy outside of marriage and the existence of promiscuity. Even other reasons are entangled in debt so that the family has the heart to sell their daughters to others so that debts can be paid. Other factors are the sophistication due to technological developments, introductions through social media, the Facebook network, and Instagram. So that, there are communication and dating, or it could be because the other is an ordered bride, turns out to be married to a foreign national, and invited to return to their country where the men sell his wife to someone else (Mubasyaroh: 2016).

A very young marriage for a girl can damage her reproductive health, a child marries and has intercourse but it is precisely what happens a lot that miscarriages, and her reproductive organs suffer damage, besides that her psyche is also unstable, still a child and there is no selfmaturation and there is no can be responsible in providing sustenance to his wife and children, responsibility as a family head, and what often happens is emotion, infidelity and running away from all duties both as a husband, or as a wife (Hanum \& Tukiman, 2015).

Various regulations governing the minimum age for marriage in Indonesia, namely in marriage law number 1 of 1974, if the men have reached the age of 19 years and women reach the age of 16 years, while in article 29 of the civil law stated that each man those who are not yet 18 years old and women who are not however 15 years old, have not been able to carry out 
marriages, but if there are important reasons the president can lift the ban by giving dispensation. According to law number 35 of 2014 concerning amendments to law number 23 of 2002 concerning the protection of children that the category of children is between the ages of 8-18 years (Iriani, 2015). Based on the description above, the author is interested in raising the issue of how is the polemic of early marriage and its effects and consequences on domestic violence.

\section{RESEARCH METHOD}

This study uses qualitative research, while the research method is normative juridical that is by reviewing the literature or books as well as existing laws and regulations. Related to the problem to be studied and carried out and data analysis techniques obtained namely by library research, by examining primary legal materials, and secondary and tertiary (Ibrahim, 2010).

\section{RESULTS \& DISCUSSION}

\section{a) Women and Their Protection}

The protection of all citizens is a duty of government, state, and law. The term woman is part of a man's rib, which does not mean the husband is free to do anything to his wife because he considers a woman as his wife. This is influenced by the patriarchal culture, which requires that women cannot be free to do anything. This does not only relate to households but also covers broader domains such as social, government, and even education (Lestari Suryamizon, 2017).

A woman is considered as a weak and very vulnerable creature, so there is an assumption that she cannot work hard, but her nature is considered to give birth and become a housewife or servant of her husband and child. With the age that continues to grow and the emancipation of women, of course, it cannot be left alone, a woman has the same rights and should not be underestimated. The protection of women is about going to education about getting an education as accurately as others. There should be no difference in the protection of health and proper care for their reproductive organs. Work safety, permission for marriage, childbirth, not overtime at night, and the right to be protected from all violations that threaten women's safety (Gultom, 2014) 
Protection can be interpreted as efforts to guarantee the welfare of a woman of her right to live, especially the rights that are considered to be related to her human rights, where such rights can guarantee gender equality in the lives of men and women, gender equality meant in the existence of justice and equality of rights in all fields and equality also does not look at ethnicity, race and among groups, the appreciation of that right exists where it is stated in the rights in the law, and the rights are made in writing (Gusmasyah, 2019).

The National Commission on Violence against Women (Komnas Perempuan) is an independent state institution in Indonesia established as a national mechanism to eliminate violence against women. The institution is authorized to make regulations specifically protecting women. Women's protection includes juridical and non-juridical protection. Juridical protection is protection that uses laws and regulations. There is a written guarantee in the protection of women, and anyone who violates will be subject to sanctions. Nonjuridical protection emphasizes the education and health sectors (Lionel Laurika, 2016). Women have the right to the highest education possible without intimidation and coercion from anyone including from their own husbands.

\section{b) Early Marriage}

Early Marriage is a marriage that is done when the age is not ripe. This has the effect of immaturity, which has the potential inability to be responsible as the head of the family. Father or mother in marriage at a young age also has the potential to be a means of exploitation. These early marriages often and often occur in rural areas but do not close the possibility also exist in urban areas, mostly in rural areas due to frequent economic problems or due to debt and debt, and from families unable and unable to pay, so selling their daughters to people or replace the deficit with his child.

This condition is very alarming but even more sad that lending money will be returned or paid off the debt with a child who is still young. This is often the case and very alarming, because of the difficulty of economic life so that flesh and blood itself finally sold to pay off all debts -the debt and in fact, there should be carried out a large-scale punishment to crack down on the offender (Rubin, 2019).

Other causes that also often occur due to promiscuity, technological sophistication, and lack of supervision from parents, are acts that cause pregnancy out of wedlock and embarrasses the family (Prastyananda, 2016). Finally, the young couple was married, the question arises whether their marriage is ready to be born and inner? Are they prepared to 
get married? Can be said not prepared, why? Because when they go too far, it could be due to lust or other things that encourage them to do that too far, so as a result, forced to be responsible (Jayani, 2019). How to become a father or mother, even though they have not found work, and have not been able to account for all will the necessities of life and household but are required to be able to fulfill everything, and this can or can impact on divorce.

\section{c) Impact and Effects of Early Marriage}

Marriage at a very young age has a negative and bad effect on the development of young couples who marry at a very young age. The impacts and consequences that often occur are (Puji, 2015).

i) As a result of early marriage often results in children born dead, or even born in disability or even premature, damage to reproductive health organs can also occur in children who marry at a young age, namely under or around nineteen years and below.

ii) Emotional and emotional outbursts that are not yet stable or can be said to be high emotions can cause domestic violence. This violence does affect not only women but also the protection of a child. A child who does not know anything become victims, get traumatized, mental and psychological damage, and psychology because they see their parents fighting and fighting, not to mention if children become victims of domestic violence.

iii) According to Maisah (Maisah, 2016), The occurrence of divorce at a young age, due to domestic violence will eventually open the way to separation. The intended separation is divorce and consequently returns to the protection of children. Children should have protection and love from their parents but instead, suffer. If with marriage, father or mother protection and affection for their children is okay. But the opposite happened, the child predator is the closest person, and must always be vigilant.

iv) Interrupted access to education has resulted in many daughters being unable to continue their education to a higher level because they have to take care of their household and take care of their husband or take care of their children. Women today, get justice and gender equality in getting an education (Laharnar et al., 2015). 
In ancient times women who were married at a young age had difficulty accessing educational facilities. It is complicated for women to obtain or continue their education as before.

\section{d) Domestic Violence}

What is meant by violence in the domestic sphere is violence in the personal or household, and this act is very private, where victims often cover most of this violence and do not want the shame of his family exposed or known to many people(Hadiati Soeroso, 2010).

Domestic violence referred to in Law Number 23 of 2004 concerning the Elimination of Domestic Violence. Physical abuse, whether caused by a blunt and pointed object, or done by hand such as choking and causing pain, injury, and also severe injury, is governed by regulations. Based on the provisions of articles 351 to article 358 , which is about the persecution that is divided into minor, severe, and maltreatment and abuse, committed by a husband to his wife. Otherwise, a woman may retaliate against the husband (Bradley, 2015), which can result in death or death.

If the resulting serious injuries are punishable by a sentence of 5 (five) years in prison, as well as the 90th article in the Criminal Law Code that is a wound that a) falls ill or gets an injury that does not give hope that it will heal at all, or that can cause a deadly danger, b) inability continuously and periodically in carrying out or continuing the job position or also livelihood work, c) loss of one of the senses, with the damage resulting in one part of his body cannot function as available when, d) getting a severe disability, it can be said to have a severe impairment because parts of his body are no longer working, e) suffer from pain and paralysis means that due to a blow to his body resulting in both the victim's legs cannot walk as usual, lose their sensation, stiff and ultimately unable to move and result in having to sit in a wheelchair alias in pain, $\mathrm{f}$ ) disruption of a power of thought for four weeks or more and can be caused by nerve tissue and also the brain cannot think the results of the collision of an object, and can be the result of others who did not know him and the lack of awareness and self-forgetfulness. g) the death or death of a woman's womb, this can mean a woman who is pregnant gets violence from her husband, exposed to the abdomen, resulting in a fetus in the belly of a miscarriage and does not become a child anymore. 
Psychic violence is violence that can result in low or meaningless someone because they are considered to have no self-esteem or lower self-esteem (Mayasari, 2017), such as glaring, cursing, at least issuing words that contain insults or also as an expletive and inappropriate or improper to say, with this psychological violence will have a mental and psychological impact on women and their children. It could be because this psychological violence resulted in children and his wife are depressed and under severe stress and ultimately committed suicide, and this is what is called a victim in the sphere of domestic violence.

Sexual Violence within the scope of marriage, or so-called marital rape, is violence by coercion to require his wife to have sexual relations according to his wishes, even though the woman is his wife. Still, for whatever reason, no sexual coercion should be carried out, sexual relations can only be carried out, and indeed in sex and violence has long been felt by women since the time of the peace war (Houge \& Lohne, 2017). If you want the same you want, there is an agreement between the two parties, so it is not because of coercion, the wife may not be willing to serve her husband because of fatigue, tired from coming home from work or coming back from work or due to other reasons due to menstruation or menstruation, or can be due to illness, so as a husband must understand at least that the wife does not want at that time to serve himself, and

The last or the fourth violence is Violence in Abandonment of the Household is commonly referred to as economic neglect, intended is a husband who travels far to find work to meet (Prantiasih et al., 2016). His financial needs as the backbone of the family, apparently since his departure which is counted for ten years in a row there has never been news and news and does not provide economical income, this is also mentioned by economic neglect because it allows children and his wife to live in poverty without sending money and no the news, this is what is called domestic violence

The polemic of early marriage is very vulnerable to domestic violence due to unpreparedness in fostering the household, and "forced" to do it because of the accountability demanded, and not from within. So there is no readiness for maturity, whether economic, mental, psychological maturity, attitudes, and so forth are not ready so that it always leads to violence as a form of impingement and ultimately divorce. The fact is often the men give information with a variety of motives tang in his testimony so as not to blame(Leisring \& Grigorian, 2016). According to Zuhdi (Zuhdi et al., 2019), that 
domestic violence can also be caused by Nushuz, so that the participation of families, communities and government is needed, to increase the supervision of children as a young generation so that the number of early marriages in Indonesia can be reduced.

\section{CONCLUSION}

Polemic in a marriage that is still young or early can have an impact and also results in private or domestic violence, because at a young age, it is considered the unstable soul and mental and psychological, and do not have the maturity or age enough to think or lead a household so that the consequences bring domestic violence, namely physical or physical abuse, as well as psychological violence, violence in the sexual sphere, as well as economic neglect or violence.

\section{REFERENCES}

Bradley, M. S. (2015). Gender and the acceptance of retaliatory violence among acquaintance, dating, and marital relationships. Violence and Victims, 30(3), 377-392. https://doi.org/10.1891/0886-6708.VV-D-13-00169

Gultom, M. (2014). Perlindungan Hukum Terhadap Anak dan Perempuan. Refika Aditama.

Hadiati Soeroso, M. (2010). Kekerasan Dalam Rumah Tangga Dalam Perspektif Yuridis Viktimologis. Sinar Grafika.

Hartono, B. (2014). Bentuk perlindungan hukum terhadap perempuan pelapor selaku saksi korban kekerasan dalam rumah tangga. Keadilan Progresif, 5(26), 1-19. http://jurnal.ubl.ac.id/index.php/KP/article/view/436

Houge, A. B., \& Lohne, K. (2017). End Impunity! Reducing Conflict-Related Sexual Violence to a Problem of Law. Law and Society Review, 51(4), 755-789. https://doi.org/10.1111/lasr.12294

Ibrahim, J. (2010). Teori dan Metodologi Penelitian Hukum Normatif. Bayumedia Publishing.

Jayani, D. H. (2019). Di Mana Kekerasan terhadap Perempuan Kerap Terjadi? Kekerasan terhadap Perempuan di Ranah Publik Berdasarkan CATAHU Komnas Perempuan 2019. https://databoks.katadata.co.id/datapublish/2019/09/25/di-mana-kekerasan-terhadapperempuan-kerap-terjadi

Laharnar, N., Perrin, N., Hanson, G., Anger, W. K., \& Glass, N. (2015). Workplace domestic violence leave laws: Implementation, use, implications. International Journal of Workplace Health Management, 8(2), 109-128. https://doi.org/10.1108/IJWHM-03-20140006

Leisring, P. A., \& Grigorian, H. L. (2016). Self-Defense, Retaliation, and Gender: Clarifying Motivations for Physical Partner Violence. Journal of Family Violence, 31(8), 949-953. https://doi.org/10.1007/s10896-016-9874-3

Lionel Laurika, A. (2016). Perlindungan Hukum Terhadap Korban Tindak Pidana Kekerasan Dalam Rumah Tangga. Lex Crimen, 5(2), 30-36. 
Maisah, M. (2016). RUMAH TANGGA DAN HAM: Studi atas Trend Kekerasan dalam Rumah Tangga di Provinsi Jambi. Musãwa Jurnal Studi Gender Dan Islam, 15(1), 125. https://doi.org/10.14421/musawa.2016.151.125-128

Mayasari, D. E. (2017). Tinjauan Normatif Perlindungan Hukum Terhadap Istri Korban Kekerasan Dalam Rumah Tangga. Refleksi Hukum: Jurnal Ilmu Hukum, 1(2), 175. https://doi.org/10.24246/jrh.2017.v1.i2.p175-190

Prantiasih, A., Yuhdi, M., \& Awaliyah, S. (2016). Model perlindungan hak perempuan korban tindak kekerasan dalam rumah tangga. Jurnal Pendidikan Pancasila Dan Kewarganegaraan, 28(1), 15-19.

Rubin, A. T. (2019). Punishment's Legal Templates: A Theory of Formal Penal Change. Law and Society Review, 53(2), 518-553. https://doi.org/10.1111/lasr.12400

Runi, I. (2019). Catatan Tahunan 2019 Komnas Perempuan: Kasus Kekerasan terhadap Perempuan Meningkat. https://www.jurnalperempuan.org/warta-feminis/catatan-tahunan2019-komnas-perempuan-kasus-kekerasan-terhadap-perempuan-meningkat

Zuhdi, S., . K., Prakosa, A. L., Kurnianingsih, M., Astuti, W., \& Rahman, R. A. (2019). Domestic Violence As A Consequence Of Nusyuz Under The Islamic Law And Legislation Of Indonesia. Humanities \& Social Sciences Reviews, 7(2), 340-348. https://doi.org/10.18510/hssr.2019.7240 